\title{
The German literature in American exile - great writers and their wives: perspectives from Russian scholars
}

\author{
Svetlana Averkina ${ }^{1, *}$, Angelika Kalinina $^{1}$, and Tatiana Suchareva ${ }^{1}$ \\ ${ }^{1}$ Linguistics University of Nizhny Novgorod, 603115, 31-a Minina str., Nizhniy Novgorod, Russia
}

\begin{abstract}
The article focuses on the life and art of the famous Germane writers, namely Thomas Mann, Lion Feuchtwanger, and Franz Werfel. After the outbreak of WWII, when the Nazi forces invaded these lands, a lot of emigres managed to leave for the USA. For many of them, the escape route was extremely turbulent. The German writers in the USA settled closely together in California, forming a tight community. The famous Germane writers had to decide upon two principal questions: what they could do for the culture of their home country while staying in exile, and how to interact with the culture of the country where they live. In this connection, it is of great importance to analyze not their works, but the books of their wives. They took care of the house and children on a daily basis, as well as became secretaries, councilors, and closest associates of their great husbands. The authors also propose the main perspectives on a future research on this topic, focusing on the social and political phenomenon of "the community of German writers in American exile", analyzing how the intellectual community was formed, discussing the documents of this age, studying the memories about their time in America in the context of the contemporary gender theory.
\end{abstract}

\begin{abstract}
Nowadays the problem of refugee adaptation remains extremely difficult and concerns almost all European countries and the USA. In crisis times, groups of individuals sharing views opposed to the ruling regimes in their home countries were banished by force and had to settle abroad, forming expat communities: Jews during the inquisition, Puritans under King Jacob, Huguenots after the Wars of Religion, and the White Russians during the Russian Revolution. The most woeful, large-scale, and unconceivably atrocious exodus was caused by the prosecution of the unwelcome and the other-minded that started in Germany when Hitler came into power in 1933.

Any wave of migration affects, above all, the most active social groups, such as the intellectuals (scientists, students, artists), all those who try to escape the terrors of war and life without any hopes for the future. During the first year of NSDAP rule, many writers, artists, musicians, and journalists fled their homes seeking for asylum in France, Austria, Netherlands, and other European countries [2].
\end{abstract}

* Corresponding author: averkina.svetlanalunn@mail.ru 
At the outbreak of WWII, when the Nazi forces invaded these lands, many emigres managed to leave for the USA. For many of them, the escape route was extremely turbulent. Leon Feuchtwanger was interned in France as a German resident and could escape to Spain only in disguise and owing to the tremendous efforts of his wife Marta. The other captives detained in the camps were later sent to Auschwitz. Walter Benjamin was less lucky: threatened to be deported back to France by the Spanish authorities, he committed suicide.

The passage of German intellectuals to the USA was facilitated by independent foundations (the state remained neutral and government bodies did not assist), such as the Emergency Rescue Committee managed by Varian Fry, or a group of Quaker volunteers from the Unitarian church, or important individuals, including Eleanor Roosevelt, the spouse of the US President [1, pp. 2-12].

German writers in the USA settled closely together in California, forming a tight community. Feuchtwanger bought Villa Aurora in Pacific Palisades. Thomas Mann and his family lived nearby in a villa on San-Remo Drive; Franz Werfel bought a house in Beverly Hills. In the USA, the writers had the chance to give lectures and speak to wide audience.

Paul Thomas Mann (1875-1955) was the most popular novelist, short story writer, social critic, philanthropist, essayist, and the 1929 Nobel Prize laureate. His highly symbolic and ironic epic novels and novellas are noted for their insight into the psychology of artists and intellectuals. His analysis and critique of the European and German soul used modernized German and Biblical stories, as well as the ideas of Goethe, Nietzsche, and Schopenhauer. He was a member of the Hanseatic Mann family. His older brother was the radical writer, Heinrich Mann, and three of his six children, Erika Mann, Klaus Mann, and Golo Mann, also became important German writers. Thomas Mann is one of the best-known exponents of the so-called "Exilliteratur", literature written in German by those who opposed or fled the Hitler regime. Mann's work influenced many future authors. Lion Feuchtwanger (1884-1958) was a German-Jewish novelist and playwright, a prominent figure in the literary world of Weimar Germany, he influenced contemporaries in many ways. In his writings, Feuchtwanger exposed Nazi racist policies years before the British and French governments abandoned their policy of appeasement towards Hitler. Also, Feuchtwanger was a great connoisseur of people and a specialist in human history [3].

During the exile in America, he was very often translated by June Barrows Mussey and other good writers. In New York, a Yiddish translations of his books were in book stores and quite popular. At the end of life, he dealt with Jewish themes very much and advocated a Jewish state as a refuge. In 1957, he became ill with stomach cancer. After several operations, he died from internal bleeding in late 1958. His wife Marta continued to live in their house on the coast and remained an important figure in the exile community, devoting the remainder of her life to the work of her husband. Before her death in 1987, Marta Feuchtwanger donated her husband's papers, photos, and personal library to the Feuchtwanger Memorial Library to be housed within the Special Collections of the Doheny Memorial Library at the University of Southern California.

Franz Viktor Werfel (1890 -1945) was an Austrian-Bohemian novelist, playwright, and poet whose career spanned World War I, the Interwar period, and World War II. He is primarily known as the author of "The Forty Days of Musa Dagh" (1933). A novel based on events that took place during the Armenian Genocide of 1915. His novel "The Song of Bernadette" (1941) is developed the life and visions of the French Catholic saint Bernadette Soubirous, which was made into a Hollywood film of the same name.

Franz Werfel died in Los Angeles in 1945 and was interred there in the Rosedale Cemetery. However, his body was returned in 1975 to Vienna for reburial in the Zentralfriedhof. On the memorial to Franz Werfel by Ohan Petrosian in Schiller Park in Vienna, there is the inscription: "In Dankbarkeit und Hochachtung das Armenische Volk" ("In gratitude and respect, the Armenian people") [3]. 
Also, these famous German writers, many of whom had a scarce knowledge of English at the beginning of the exile-time had to decide upon two principal questions: what you can do for the culture of your home country while you stay in exile, and how to interact with the culture of the country where you live? In this connection, it is interesting to analyze their works.

For 16 years spent by Feuchtwanger in the USA, he wrote more than ten novels, including "The Lautensack Brothers" (1942), "Foxes in the Vineyard" (1947) and "Goya" (1951). Franz Werfel wrote "The Song of Bernadette" (1941), his last novel "Star of the Unborn," and prepared the complete edition of his works. Thomas Mann finished the tetralogy "Joseph and his brothers" (1933-1943), "Lotte in Weimar" (1939), wrote "Doctor Faustus" (1947), "The Holy Sinner" (1951), "Confessions of Felix Krull" (1954), created a series of radio programs "Germany and Germans," and articles on the history of German literature.

Little by little, the writers got acquainted with Americans culture, their new homes attracted Charlie Chaplin, Albert Einstein, Charles Lauton, and many other contemporary celebrities. In the same way as in Europe, they managed to form the centers of intellectual gravity. Nowadays the Villa Aurora works as a foundation, which supports artists and writers. Thomas Mann;s American house has been bought by the German government with the same purpose.

The refugees faced not only intellectual, but also mundane problems: how to settle in the new world? Their women, Marta Feuchtwanger, Katia Mann, and Alma Maler Werfel, have been of invaluable assistance in life and work arrangement during the American exile. They took upon themselves daily cares and homemaking, but also became secretaries, councilors and closest associates of their great husbands.

Each of these women had an individual character and temper. None of them remained voiceless. They all wrote memoirs, many letters and biographical notes: "My life" (1964) by Alma Maler Werfel, "My Unpublished Notes" (2000) by Katia Mann, "Just a Woman" (1983) by Marta Feuchtwanger. These texts are interesting not only with their content and themes - most of the facts are already well known to the readers and experts - but also with their narrative style, which is traditionally analyzed in the scope of Gender Studies.

Alma was a femme fatal of her time and focused on herself and a bit less on the her great husbands and friends: Maler, Gropius, Kokoshka, and Werfel. Her dominant intention was self-affirmation.

Katia Mann (born Pringsheim) and Marta Feuchtwanger (born Löffler) were typical Jewish wives, ready to be a shadow of their husbands, strong, taking charge of all difficulties. Marta helped her husband to escape the imprisonment, repaired her house with her own hands, accommodated her guests and anyone who wished to stay in a comfortable villa. Katia also showed a remarkable force of character when she brought up six children and helped her husband at work [4].

The main driver of Marta's autobiography is service. The memoirs of Katia Mann can hardly be called an autobiography at all. She almost never writes about herself. She dictated her memories to Elisabeth Plessen and her son Michael Mann. She gives an example of selfsacrifice. "I never could do what I wanted..." - this is the beginning of Mrs. Thomas Mann. "The life of Katharina Pringsheim" is her biography written by Inge and Walter Jens (2003). This book's name by itself shows the intent to be absorbed by the personality of her husband; however, this idea is contested by the book authors [5].

Such studies can be interesting for the audience of Gender Studies. Problems of gender poetics are practically not mastered in the domestic literary criticism. This largely determines the relevance of the appeal not only to the so-called "female prose", but also to more responsible sources: memoirs, diaries, and letters. The fact is that "feminine style" can be imitated based on the stereotypes described and analyzed by many linguists. Sometimes a man hides under the mask of a woman's author. In the case of memoir prose, non-fiction 
texts, the gender of the author is beyond doubt. It is all the more interesting to see exactly how certain events are described to characterize personal style, handwriting, durtus narrators.

To conduct this kind of work, it is interesting to look at repetitive motifs, constant epithets, and through symbols of the texts of the authors under study. Neither Katya Mann, nor Martha or Alma were great writers. Their texts alone could not serve as material for the study of poetic methods or principles.

Analysis of the memoirs of K. Mann showed that the pronoun "I" in its text is used much less than in "My Life" by A. Mahler. Her memories are characterized by a more rigorous description of events in the life of the family. The style is businesslike. Often there are structures in the passive voice. The main leitmotifs are "dienen," "helfen," "mitfühlen," and other verbs of "service." It creates the image of a voluntary sacrifice, self-denial, rejection of excessive emotionality and obsession, dissolution in events. This style can be called epic, restrained [6].

For the memoirs and letters of Martha, the motive of "adventure," "escape" is very characteristic. Her text is replete with images of various exotic places that spouses have visited or would like to visit. She is often ruthless towards people and events and is able to criticize and condemn the weakness and impropriety of others. The syntax is characterized by significant expressiveness, perseverance. Epithets are often associated with the semantic field of "power" [7]. The active nature of Martha Feuchtwanger, her sporting spirit was also manifested in the artistic style of the memories. It seems that her goal was not to document (like K. Mann did) the events of her husband's life, but to describe the mood of the era in which they had a chance to live. There are paradoxical judgments in the text. They are characterized by Jewish humor and striking irony, which helped March to cope with difficulties. Her literary mask is a mother, keeper, savior, protector. Most likely, in the life of her role was expressed in this [8].

The book "My Life" by Alma Mahler became a bestseller in Europe and suffered from all the shortcomings of this type of literature. Mahler's style cannot be called intricate, but the language is figurative. It is distinguished even by some poverty, which contrasts with the heat of passions and the density of the material offered. The writer makes herself a real heroine of a love story. Her subjects of interest are the great men of the epoch - Gustav Mahler, Oskar Kokoschka, Walter Griffius, and many of her supposed admirers. Alma practically does not give them a voice: does not quote, does not give fragments of letters. The reader will learn about events from her words. Almost the entire text is authoritatively filled with her impressions. It is difficult to call this type of narration biographical material in its pure form. These are memories that do not pretend to the accuracy of the document, interesting impressionistic images of episodes of the past, their deeply personal interpretation. An interesting fact is that this text was translated into English early and read in English very naturally. Perhaps America's lifestyle was closest to lovers of thrills, long parties, and easy conversations [9].

Separately, I would like to emphasize the difference in the description by these three women of the same events, facts of life in the "'California Paradise" in the most difficult period of history for Germany and Austria. It is understandable why the fate of K. Mann, M. Feuchtwanger, and A. Mahler-Werfel aroused the interest of many researchers and even some linguists, although this aspect may be the subject of more careful study, especially in the comparative aspect.

The biographies and studies dedicated to these great women provide more useful and interesting materials:

- Oliver Hilmes: Witwe im Wahn Siedler, München 2004;

- Manfred Flügge: Die vier Leben der Marta Feuchtwanger, Aufbau-Verlag, Berlin 2008;

- Inge and Walter Jens: Mrs. Thomas Mann. The life of Katharina Pringsheim. Rowohlt. Reinbek, 2003; 
- Kirsten Jüngling / Brigitte Roßbeck: Katia Mann. The Wizard's Wife. Propyläen, 2003;

- Hildegard Möller: Die Frauen der Familie Mann. Piper, München/Zürich, 2004.

They were also depicted in some documentary and feature films:

- Ken Russel, "Mahler”(1974);

- Koehler, Robert, "Bride of the Wind" (2001);

- Heinrich Breloer, "The Manns - Novel of a Century" (2001).

On the basis of all the above, it is possible to determine the main perspectives of a research design as follows: (a) to describe the social and political context of such phenomenon as "the community of German writers in American exile"; (b) to analyze how the intellectual community was formed, tracing how it interacted with the host and the home country; (c) to describe the life of the Manns, the Feuchtwangers, and the Werfels, as well as the guests and friends of their hospitable houses, introducing to a wide audience the main problems of their works, highlight the concepts characteristic for critical, publicist and literary texts of the exile; (d) to find and describe the documents of the age (being illustrative of the life and work of great German writers' wives), to study their memories about life in America in the context of contemporary Gender Studies.

\section{References}

1. E. Bloch, Grundbegriffe und Autoren ostmitteleuropäischer Exilliteraturen 1945-1989. Ein Beitrag zur Systematisierung und Typologisierung (2004)

2. M. Mauthner, German Writers in French exile, 1933-1940 (2007)

3. M. Ephimova, American shelter of Lyon Feuchtwanger (Radio Svoboda, 2010)

4. C. Mann, Erinnerungen und Gedanken. Eine Jugend in Deutschland (1986)

5. K. Mann, My unpublished notes (2000)

6. I. and W. Jens, Mrs. Thomas Mann: the life of Katharina Pringsheim (2003)

7. M. Feuchtwanger, Just a woman (1983)

8. M. Flügge, Die vier Leben der Marta Feuchtwanger (2008)

9. A. Maler-Werfe, My life (1964) 